\title{
Serum Ischaemia-modified Albumin Concentration in Hyperemesis Gravidarum
}

\author{
Hipermezis Gravidarumda Serum İskemi-modifiye Albümin Düzeyleri
}

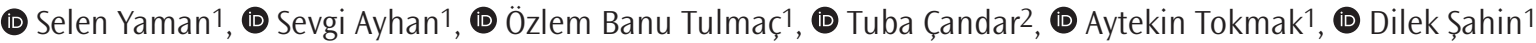 \\ 1University of Health Sciences Turkey, Ankara Dr. Zekai Tahir Burak Women's Health Training and Research Hospital, Clinic of Obstetrics and \\ Gynecology, Ankara, Turkey \\ 2Ufuk University Faculty of Medicine, Department of Clinical Biochemistry, Ankara, Turkey
}

\begin{abstract}
Introduction: The role of oxidative stress in the pathogenesis of hyperemesis gravidarum (HEG) has been demonstrated in a lot of studies. The present study aimed to compare the ischaemia-modified albumin (IMA) serum levels of patients diagnosed with HEG with healthy pregnant women, and to investigate whether oxidative stress caused increased serum IMA in HEG.
\end{abstract}

Methods: Pregnant women were classified into a group diagnosed with HEG $(n=45)$ and an age- and body mass indexmatched control group without HEG $(n=45)$. Serum IMA levels were assessed by the enzyme-linked immunosorbent assay (ELISA) method.

Results: Serum IMA levels were higher in the HEG group than the control group (HEG: $8.2 \pm 0.2 \mathrm{ng} / \mathrm{mL}$, control: $6.9 \pm 0.3 \mathrm{ng} /$ $\mathrm{mL}, \mathrm{p}<0.001)$.

Conclusion: We found that HEG was related to increased maternal serum IMA levels. The high levels of IMA in HEG can be considered as a reflection of increased oxidative stress.

Keywords: Ischaemia-modified albumin, oxidative stress, hyperemesis gravidarum

\section{öZ}

Amaç: Birçok çalıșmada hiperemezis gravidarumun (HEG) patogenezinde oksidatif stresin katkısı gösterilmiştir. Bu çalışmada, HEG tanısı konulan hastalarla sağlıklı gebe kadınların serum iskemi modifiye albümin (IMA) düzeylerini karşılaştırmak ve oksidatif stres belirteci olan IMA'nın HEG'de artıp artmadığının araștırılması amaçlanmıștır.

Yöntemler: Yaş ve vücut kitle indeksine göre eșleștirilmiş hastalar, HEG tanısı alanlar $(n=45)$ ve sağlıklı gebe kontrol grubu $(n=45)$ olarak ikiye ayrıldı. Serum IMA düzeyleri, her bir katılımcı için enzim bağlı immün assay (ELISA) yöntemi ile analiz edildi.

Bulgular: Serum IMA düzeyleri HEG grubunda kontrol grubuna göre daha yüksekti (sırasıyla HEG grubu $8,2 \pm 0,2 \mathrm{ng} / \mathrm{mL}$, kontrol grubu 6,9 $\pm 0,3 \mathrm{ng} / \mathrm{mL}, \mathrm{p}<0,001)$.

Sonuç: HEG grubunda maternal serum IMA düzeyinin anlamlı yüksek olduğunu bulduk. HEG'de tanımlanan yüksek iMA seviyeleri, oksidatif stresin bir yansıması olarak düşünülebilir.

Anahtar Kelimeler: İskemi modifiye albümin, oksidatif stres, hiperemezis gravidarum

\section{Introduction}

Nausea and vomiting (NV) are common experiences in pregnancy, affecting $70 \%-80 \%$ of all pregnant women (1). Hyperemesis gravidarum (HEG) affects the quality of life of women during pregnancy; it is considered as the third leading cause of all hospitalisations during pregnancy (2). In other words, HEG is a serious clinical condition responsible for one-third of all hospitalisations during pregnancy (3). HEG is a severe and persistent form of NV that affects about $0.3 \%-2 \%$ of all pregnancies, resulting in fluid loss, electrolyte imbalance, nutrition deficiency, at least $5 \%$ weight loss and ketonuria (4). Endocrine (human chorionic gonadotropin, estradiol and progesterone), immunologic and personal factors (increased body weight) are responsible for the etiopathogenesis of the disease (5). In addition, certain pathologic factors such as lipid disorders, activation of sympathetic system, thyroid disorders, increase in systemic oxidative stress and Helicobacter pylori infection are frequently mentioned in the pathophysiology of the disease $(6,7)$. However, there is no theory that explains the differences in the clinical diversity of HEG and combines various pathogenetic factors under one roof.

Ischaemia-modified albumin (IMA) is used as a biomarker in the early diagnosis of acute coronary syndrome (8), acute ischaemia that is approved by the Food and Drug Administration and is considered as a marker for elevated free radical-induced protein oxidative injury $(9,10)$. 
It has been observed that various ischaemic events such as stroke, acute mesenteric ischaemia and some cancer types have an effect on IMA levels (11-13). IMA is formed as an end product of modification in serum albumin caused by the reactive oxygen derivatives that emerge because of ischaemia. The amino terminus of the albumin molecule is a binding for metal ions such as nickel, cobalt and copper. However, when exposed to ischaemia, hypoxia and/or free radical damage, the amino terminus region of albumin is more susceptible to degradation when its ability to bind to metals is reduced, forming IMA. Its serum concentration is not related to age or gender (14). IMA represents 1\%-2\% of total serum albumin in non-pathological cases, and this ratio increases to $6 \%-8 \%$ during ischaemic conditions (14). Normally, pregnancy occurs in hypoxic intrauterine environment; the ensuing reperfusion and placental oxidative stress lead to the physiological development of syncytiotrophoblast. Previous studies demonstrated that IMA can be a marker for hypoxic intrauterine environment, especially in early pregnancy (15-17). In this study, we assumed that HEG was related to increased maternal serum IMA level because of oxidative stress during the early period of pregnancy. Therefore, we designed the present study to evaluate the clinical utility of IMA in HEG by comparing its serum concentrations between the HEG patients and gestational age-matched healthy pregnant women.

\section{Methods}

This study was conducted at the University of Health Sciences Turkey, Zekai Tahir Burak Women's Health Training and Research Hospital. Patients enrolled in the study were selected on the basis of their diagnosis with HEG and healthy pregnant women who were admitted to the antenatal clinic during the $6-14^{\text {th }}$ week of pregnancy.

This study was approved by the local ethical committee of the hospital (decision no: 7, date: 25.05.2016), and written informed consent of all participants were obtained. The study was designed and conducted according to the principles of Helsinki Declaration (18). The participants were divided into two groups: study and control. Both groups' gestational ages (between 6- and 14 weeks' gestation) and ages (20-37 years) were matched.

The following diagnostic criteria were used for HEG: severe NV throughout the pregnancy ( $>3$ times per day), more than $5 \%$ weight loss and at least one positive ketonuria in the urine test.

Criteria were excluded for multiple gestation, hypertensive disorders of pregnancy, diabetes mellitus, gestational trophoblastic disease, any type

Table 1. Demographic and clinical data of the subjects

\begin{tabular}{|l|l|}
\hline & Control $(\mathbf{n}=\mathbf{4 5})$ \\
\hline Age (year) & $27(20-37)$ \\
\hline Body mass index $\left(\mathbf{k g} / \mathbf{m}^{2}\right)$ & $28.84(21.3-37.3)$ \\
\hline Gestational age (week) & $10.24 \pm 1.09$ \\
\hline Gravida (range) & $2(1-4)$ \\
\hline Parity (range) & $1(0-2)$ \\
\hline
\end{tabular}

of existing gastrointestinal, hepatic and renal diseases or inflammatory diseases, eating disorders, psychiatric disease and other known probable vomiting causes, such as thyroid disorders.

Gestational age was calculated according to the last menstrual period or first trimester ultrasound examination of those women who did not remember their last menstrual period. Body mass index (BMI) was determined by dividing the body weight (kilograms) with the square of height in metres. All HEG patients in the study group were hospitalised for at least 24 hours for initial treatment. They were hydrated at the time of admission to avoid the possible effects of hypovolemia. It was observed that vital signs and urine output of the patients were normal before blood samples were taken. Fasting blood samples were taken from the antecubital vein without the use of anticoagulants. Serum IMA concentrations were analysed by a commercially available enzymelinked immunosorbent assay (ELISA) kit (Eastbiopharm Human Ischaemia Modified Albumin ELISA Kit) for IMA (Chemwell 2900, Aurenesness, USA).

Intra- and inter-assay coefficients for IMA were $<10 \%$ and $<12 \%$, respectively. Blood samples were collected after an overnight fast, and centrifugation was performed at $4000 \mathrm{rpm}$ for 10 minutes with the supernatant serum frozen and stored at $-80{ }^{\circ} \mathrm{C}$ until analysis.

\section{Statistical Analyses}

Statistical analyses were performed using Statistical Package for the Social Sciences (SPSS) software (version 22, SPSS Inc., Chicago, IL). Continuous variables were demonstrated as a mean \pm standard deviation or median (minimum-maximum). All normally distributed data were compared by using the Student's t-test; Data with abnormal distribution were compared by using the Mann-Whitney $U$ test. The $p$ value of less than 0.05 was regarded as statistically significance.

\section{Results}

This study included 90 women, 45 pregnant women diagnosed with HEG and 45 healthy pregnant women of same gestational age. Median ages of the HEG patients and the healthy pregnant women in the control group were found to be 27 (20-36) and 27 (20-37), respectively. Sociodemographic features of the patients were presented in Table 1. The groups did not show any statistical difference at the time of blood sampling with regard to age, gestational age, BMI and reproductive history (Table 1). Plasma complete blood count parameters, serum glucose, urea, creatinine, aspartate transaminase, alanine transaminase and thyroid-stimulating hormone levels of the groups were statistically

HEG: Hyperemesis gravidarum 
similar ( $p>0.05$ ). Serum IMA levels were found to be significantly higher among HEG patients than the control group $(8.2 \pm 0.2 \mathrm{ng} / \mathrm{mL}$ vs. $6.9 \pm 0.3$ $\mathrm{ng} / \mathrm{mL}, \mathrm{p}<0.001$ ) (Table 2).

\section{Discussion}

In this study, we found that IMA was statistically higher in the HEG group than healthy pregnant women of the control group. Although it would not be accurate to make a clear or conclusive remark regarding the oxidative stress conditions in HEG by looking solely at the IMA levels, our results showed that the oxidative stress condition in HEG could be related to IMA levels.

Many studies elucidate the role of IMA in different diseases. IMA increase is observed in ischaemia, acidosis, free radicals and hypoxia. The studies based on literature data show that in acute coronary events, IMA has a diagnostic value of 95\% when used together with troponin and electrocardiography $(19,20)$. The diagnostic value of IMA in acute coronary events have been discussed, and evidence concerning the utility of IMA in obstetrics practice has been increasing in recent years. Prefumo et al. (15) in 2007 stated that maternal serum IMA concentrations increase during early pregnancy and normal trophoblast development is related to the hypoxic intrauterine medium. Similarly, Ustün et al. (17) stated that serum IMA levels are related to the severity of preeclampsia and preeclamptic pregnancies can be detected using a pre-determined cut-off value. In contrast to these studies, Iacovidou et al. (21) showed that IMA levels in the umbilical cord blood are same between normal pregnancies and pregnancies showing intrauterine growth retardation.

The role of IMA in perinatology practice was analysed in detail in a recently published review (22). Yarcı Gursoy et al. (22) stated that increased IMA levels in pregnancies are associated with complications such as preeclampsia, intrauterine growth retardation and diabetes mellitus; however, the results of these studies should be approached prudently

Approximately $80 \%$ of women experience a severity of NV at the time of pregnancy (23). According to the study conducted by Sari et al. (24), which is one of the very few studies in literature analysing the IMA levels of HEG patients, serum IMA levels of HEG patients were observed to be significantly higher when compared to the control group. The main cause of this increase is the hypoxic medium that develops within the uterus during the early pregnancy period. Furthermore, the authors also stated that the oxidative stress in the uterus because of the hypoxic medium is also important for physiologic trophoblast development. Although it was shown that there was no significant increase in the level of IMA of HEG patients in a smaller study by Bulanık et al. (25), in our study, serum IMA levels were found to be significantly higher when compared to the control group, similar to Sari's study (Table 3). The actual treatment of HEG is empirical and suboptimal as the definitive aetiology is not clearly shown (26). Measurement of serum levels of IMA in these patients to guide antioxidant treatment or agents preventing reperfusion damage may be beneficial for the management of HEG.

\section{Table 2. Laboratory findings of the subjects}

\begin{tabular}{|c|c|c|c|}
\hline & Control $(n=45)$ & HEG $(n=45)$ & p \\
\hline WBC $\left(x 10^{9} / L\right)$ & $8.2 \pm 1.95$ & $8.6 \pm 1.81$ & 0.283 \\
\hline Haemoglobin $(\mathrm{g} / \mathrm{L})$ & $12.4 \pm 0.98$ & $12.6 \pm 0.87$ & 0.581 \\
\hline Haematocrit (\%) & $37.74 \pm 2.60$ & $38.31 \pm 2.8$ & 0.318 \\
\hline Platelet (x10\%/L) & $238 \pm 63$ & $243 \pm 50$ & 0.578 \\
\hline Creatinine (mg/dL) & $0.63 \pm 0.12$ & $0.60 \pm 0.13$ & 0.226 \\
\hline TSH $(\mu \mathrm{IU} / \mathrm{mL})$ & $1.34 \pm 0.77$ & $1.27 \pm 0.74$ & 0.063 \\
\hline AST (IU/dL) & $18 \pm 6$ & $17 \pm 7$ & 0.659 \\
\hline ALT (IU/dL) & $13 \pm 10$ & $14 \pm 8$ & 0.542 \\
\hline
\end{tabular}

Table 3. Data from previous studies of serum ischaemia-modified albumin levels in hyperemesis gravidarum patients

\begin{tabular}{|l|l|l|l|l|}
\hline & $\begin{array}{l}\text { Number of patients } \\
\text { with HEG }\end{array}$ & $\begin{array}{l}\text { Mean age of } \\
\text { patients }\end{array}$ & $\begin{array}{l}\text { Mean gestational age of } \\
\text { patients }\end{array}$ & Serum IMA levels \\
\hline Sari et al. (24) & 45 & $26.3 \pm 5.2$ & $9.1 \pm 2.6$ & $6.6 \pm 0.7 \mathrm{ng} / \mathrm{mL}$ \\
\hline Bulanık et al. (25) & 35 & $26 \pm 4.5$ & $69.7 \pm 2.3$ & $60.3-400.4) \mathrm{ng} / \mathrm{dL}$ \\
\hline HEG: Hyperemesis gravidarum, IMA: ischaemia-modified albumin & & & 0.136 \\
\hline
\end{tabular}




\section{Study Limitations}

The limitations of our study are a small number of participants, and the use of IMA levels as the only indicator of oxidative stress. In addition, as our study method is cross-sectional, IMA changes during the continuation of pregnancy were not analysed. The indicators that contribute to the evaluation of oxidative stress and inflammatory pathways would significantly increase the quality of the study. Finally, no significant difference was found between the groups in terms of biochemical parameters such as haemoglobin levels and liver and renal function tests. Although this could be considered as a factor that complicates diagnosis, it should be remembered that these biochemical parameters do not figure among the diagnostic criteria.

\section{Conclusion}

The present study demonstrated the role of IMA in the evaluation of oxidative stress, which is one of the most important factors in the pathogenesis of HEG. However, the aforementioned limitations must be considered during the evaluation of our study results, and further studies analysing the role of IMA in HEG pathogenesis should be conducted with larger patient populations.

\section{Ethics}

Ethics Committee Approval: This study was approved by the local ethical committee of the University of Health Sciences, Zekai Tahir Burak Women's Health Training and Research Hospital (decision no: 7, date: 25.05.2016).

Informed Consent: Written informed consent of all participants were obtained.

Peer-review: Internally and externally peer-reviewed.

Authorship Contributions: Surgical and Medical Practices - S.Y., S.A.; Concept- S.Y., D.S.; Design - A.T., S.A.; Data Collection or Processing - S.Y., S.A., T.Ç.; Analysis or Interpretation - Ö.B.T., A.T., T.Ç.; Literature Search S.Y., D.Ş.; Writing - S.A., Y.S.

Conflict of Interest: No conflict of interest was declared by the authors.

Financial Disclosure: The authors declared that this study received no financial support.

\section{References}

1. Einarson TR, Piwko C, Koren G. Quantifying the global rates of nausea and vomiting of pregnancy: a meta analysis. J Popul Ther Clin Pharmacol 2013; 20:171-83.

2. Bailit JL. Hyperemesis gravidarum: epidemiologic findings from large cohort. Am J Obstet Gynecol 2005; 193: 811-4.

3. Biberoglu EH, Kirbas A, Dirican AÖ, Genc M, Avci A, Doganay B, et al. Alterations in lipid peroxidation and T-cell function in women with hyperemesis gravidarum. J Obstet Gynaecol 2016; 36: 93-6.

4. Eliakim R, Abulafia O, Sherer DM. 2000. Hyperemesis gravidarum: a current review. Am J Perinatol 2000; 17: 207-18.

5. Sun S, Qiu X, Zhou J. Clinical analysis of 65 cases of hyperemesis gravidarum with gestational transient thyrotoxicosis. J Obstet Gynaecol Res 2014; 40: 1567-72.

6. Verberg MF, Gillott DJ, Al-Fardan N, Grudzinskas JG. Hyperemesis gravidarum, a literature review. Hum Reprod Update 2005; 11: 527-39.
7. Onaran Y, Kafali H, Duvan Cl, Keskin E, Celik H, Erel O. Relationship between oxidant and antioxidant activity in hyperemesis gravidarum. J Matern Fetal Neonatal Med 2014; 27: 825-8.

8. Shen XL, Lin CJ, Han LL, Lin L, Pan L, Pu XD. Assessment of ischemia-modified albumin concentrations for emergency room diagnosis of acute coronary syndrome. Int J Cardiol 2011; 149: 296-8.

9. Bar-Or D, Lau E, Winkler JV. A novel assay for cobalt-albumin binding and its potential as a marker for myocardial ischemia-a preliminary report. J Emerg Med 2000; 19: 311-5.

10. Duarte MM, Rocha JB, Moresco RN, Duarte T, Da Cruz IBM, Loro VL, et al. Association between ischemia-modified albumin, lipids and inflammation biomarkers in patients with hypercholesterolemia. Clin Biochem 2009; 42 : 666-71.

11. Sinha MK, Roy D, Gaze DC, Collinson PO, Kaski JC. Role of "Ischemia modified albumin", a new biochemical marker ofmyocardial ischaemia, in the early diagnosis of acute coronary syndromes. Emerg Med J 2004; 21: 29-34.

12. Abboud H, Labreuche J, Meseguer E, Lavallee PC, Simon O, Olivot J-M, et al. Ischemia-modified albumin in acute stroke. Cerebrovasc Dis 2007; 23: 216-20.

13. Gunduz A, Turedi S, Mentese A, Karahan SC, Hos G, Tatli O, et al. Ischemiamodified albumin in the diagnosis of acute mesenteric ischemia: a preliminary study. Am J Emerg Med 2008; 26: 202-5.

14. Sbarouni E, Georgiadou P, Voudris V. Ischemia modified albumin changes review and clinical implications. Clin Chem Lab Med 2011; 49: 177-84.

15. Prefumo F, Gaze DC, Papageorghiou AT, Collinson PO, Thilaganathan B. First trimester maternal serum ischaemia-modified albumin: a marker of hypoxiaischaemia-driven early trophoblast development. Hum Reprod 2007; 22: 2029-32.

16. Özdemir S, Kıyıcı A, Balci O, Göktepe H, Çiçekler H, Çelik Ç. Assessment of ischemia- modified albumin level in patients with recurrent pregnancy loss during the first trimester. Eur J Obstet Gynecol Reprod Biol 2011; 155: 209-12.

17. Ustün $Y$, Engin-Ustün $\mathrm{Y}$, Oztürk O, Alanbay I, Yaman H. Ischemia-modified albumin as an oxidative stress marker in preeclampsia. J Matern Fetal Neonatal Med 2011; 24: 418-21.

18. World Medical Association declaration of Helsinki. Recommendations guiding physicians in biomedical research involving human subjects. JAMA 1997; 277: 925-6.

19. Dusek J, St’ásek J, Tichý M, Bis J, Gregor J, Vojácek J, et al. Prognostic significance of ischemia modified albumin after percutaneous coronary intervention. Clin Chim Acta 2006; 367: 77-80.

20. Bhagavan NV, Lai EM, Rios PA, Yang J, Ortega-Lopez AM, Shinoda H,et al. Evaluation of human serum albumin cobalt binding assay for the assessment of myocardial ischemia and myocardial infarction. Clin Chem 2003; 49: 581-5.

21. Iacovidou N, Briana DD, Boutsikou M, Sophia L, Baka S, Boutsikou T, et al. Cord blood ischemia-modified albumin levels in normal and intrauterine growth restricted pregnancies. Mediators Inflamm 2008; 2008: 523081.

22. Yarcı Gursoy A, Caglar GS, Demirtas S. Ischemia modified albumin in perinatology. Eur J Obstet Gynecol Reprod Biol 2017; 210: 182-8.

23. McCarthy FP, Lutomski JE, Greene RA. Hyperemesis gravidarum: current perspectives. Int J Womens Health 2014; 6: 719-25.

24. Sari N, Ede H, Engin-Ustun Y, Göçmen AY, Çağlayan EK. Hyperemesis gravidarum is associated with increased maternal serum ischemia-modified albumin. J Perinat Med 2017; 45: 421-5.

25. Bulanık M, Sağsöz N, Sayan CD, Yeral Mi, Kısa Ü. Comparison of Serum Ykl40 and Ischemia Modified Albulmin Levels Between Pregnant Women with Hyperemesis Gravidarum and Normal Pregnant Women. Med Arch 2019; 73: 97-100.

26. Sanu O, Lamont RF. Hyperemesis gravidarum: pathogenesis and the use of antiemetic agents. Expert Opin Pharmacother 2011; 12: 737-48. 